\title{
A Conceptual Framework of Happiness at the Workplace
}

\author{
Phathara-on Wesarat ${ }^{1}$, Mohmad Yazam Sharif ${ }^{2} \&$ Abdul Halim Abdul Majid ${ }^{2}$ \\ ${ }^{1}$ Faculty of Humanities and Social Sciences, Prince of Songkla University, Pattani Campus, Thailand \\ ${ }^{2}$ School of Business Management, College of Business, Universiti Utara Malaysia, Malaysia \\ Correspondence: Phathara-on Wesarat, Dept. of Social Sciences, Faculty of Humanities and Social Sciences, \\ Prince of Songkla University, Pattani Campus, Pattani, Thailand. Tel: 66-7-333-1304. E-mail: \\ phatharaon-w@bunga.pn.psu.ac.th
}

Received: July 8, 2014 Accepted: October 28, 2014 Online Published: December 20, 2014

doi:10.5539/ass.v11n2p78 URL: http://dx.doi.org/10.5539/ass.v11n2p78

\begin{abstract}
Happiness at the workplace refers to how satisfied people are with their work and lives. The idea of happiness is related to individual's subjective well-being. Happiness at the workplace is crucial for improving productivity in any organization. Happy people are productive people while those people who are unhappy may not pay full attention to any task. Some scholars believe that organizations which are able to maintain long-term happiness at the workplace could probably increase and sustain productivity. Therefore, they should know what factors could affect employee happiness in order to effectively enhance happiness at the workplace. But research on employee happiness was rarely seen in the past. The issue of happiness at the workplace needs to be properly conceptualized so that useful research on it could be conducted. This paper presents a potential conceptual framework of happiness at the workplace that could give valuable contribution to future research in this area.
\end{abstract}

Keywords: conceptual framework, happiness, subjective well-being, workplace

\section{Introduction}

Work is one of important aspects of people's lives (Dulk, Groeneveld, Ollier-Malaterre, \& Valcour, 2013). People perform their work in exchange for either monetary (e.g. salary and benefits) or non-monetary rewards (e.g. psychological fulfillment from work) (Stiglbauer \& Batinic, 2012). In today's changing world, the world of work has been changing rapidly (Baran, Shanock, \& Miller, 2012; Quinlan, 2012). The changing work environments (e.g. the increasing internationalization of business, new technology, and new organizational practices) lead to the changing nature of work (Connell, Gough, McDonnell, \& Burgess, 2014; Koukoulaki, 2010). Nature of work is defined as "the actual content of the job or work characteristics" (Benrazavi \& Silong, 2013, p. 129). From human resource management (HRM) perspective, HRM practices (e.g. downsizing, outsourcing, and temporary employment) influence the nature and scope of work (Colakoglu, Lepak, \& Hong, 2006). Corporate restructuring and downsizing which aim to reduce the workforce for improving organizational performance probably can make employees feel unsatisfied with their jobs (Klehe, Zikic, Van Vianen, \& De Pater, 2011). Employees who perceive job insecurity have lower commitment to their organizations and they intend to leave their jobs (Silla, Gracia, Maňas, \& Peiró, 2010). Employees' job satisfaction has an impact on organizational performance (Dalal, Baysinger, Brummel, \& Lebreton, 2012). If they are satisfied with work, their productivity would be increased (Barmby, Bryson, \& Eberth, 2012).

Generally, employers expect a high level of performance and productivity from their employees (Thompson \& Goodale, 2006; Samnani \& Singh, 2014). Most companies need productive workers to work for them so as they could attain organizational goals (Chong \& Eggleton, 2007; Hales \& Williamson, 2010). Many companies used managerial tools for the purpose of increasing productivity (Salis \& Williams, 2010; Samnani \& Singh, 2014). The studies by Salis and Williams (2010), Samnani and Singh (2014), and Tabassi and Abu Bakar (2009) considered HRM practices (e.g. compensation system, face-to-face communication) as the means to increase productivity. Moreover, maintaining happiness at the workplace can increase employees' productivity (Quick \& Quick, 2004). The previous studies (e.g. Quick \& Quick, 2004; Rego \& Cunha, 2008) state that happy employees are productive employees. Conversely, unhappiness at the workplace reduces productivity (Fereidouni, Najdi, \& Amiri, 2013). The happiness issues have been widely studied in various fields such as philosophy, religion, psychology, sociology, and economics (Aydin, 2012). The term "happiness" has been 
discussed by many scholars (Björke, 2012; Johnston, Luciano, Maggiori, Ruch, \& Rossier, 2013). "Happiness" is universal to all people in every culture because everybody searches for happiness (Aydin, 2012; Fisher. 2010). It is related to an individual's subjective well-being (Angner, Hullett, \& Allison, 2011; Jiang, Lu, \& Sato, 2012) or life satisfaction (Van Praag, Romanov, \& Ferrer-i-Carbonell, 2010). There is a close relationship between job and life satisfaction (Saari \& Judge, 2004). Job satisfaction affects life satisfaction while life satisfaction also affects job satisfaction (Saari \& Judge, 2004). Thus, happiness at the workplace refers to an individual's work and life satisfaction, or subjective well-being at the workplace (Bhattacharjee \& Bhattacharjee, 2010; Carleton, 2009). In this paper, the two terms "happiness" and "subjective well-being" are used interchangeably (Frey \& Stutzer, 2000a).

Whereas happiness at the workplace is important to both individuals and organizations (Fisher, 2010; Simmons, 2014), the research on employee happiness in organizations is limited (Fisher, 2010; Hosie, Willemyns, \& Sevastos, 2012; Sloan, 2005). It should be investigated further in order to provide sufficient knowledge to academics, practitioners, and those who are interested in the notion of happiness at the workplace (Hosie et al., 2012; Sloan, 2005). This paper therefore develops a conceptual framework of happiness at the workplace that could be used for conducting the research on this area. It begins with conceptual framework. It is then followed by discussion, and conclusion respectively.

\section{Conceptual Framework}

This paper focused on happiness at individual level (i.e. happiness of individual employees). Based on the literature review (e.g. Angner et al., 2011; Demir, Özen, Doğan, Bilyk, \& Tyrell, 2011; Mohanty, 2009; Tadić, Bakker, \& Oerlemans, 2013), happiness constructs at the workplace were identified. The interrelations between construct categories (such as employment status, income, friendship, and work activities) and happiness were supported by the previous studies (see Table 1).

Table 1. Happiness constructs at the workplace

\begin{tabular}{|c|c|c|}
\hline Construct category & Findings & References to support the findings \\
\hline \multirow{4}{*}{ Employment status } & $\begin{array}{l}\text { Full-time employment contributes to } \\
\text { employee's happiness positively. }\end{array}$ & Mohanty (2009) \\
\hline & $\begin{array}{l}\text { Unemployment brings unhappiness to } \\
\text { people. }\end{array}$ & $\begin{array}{l}\text { Alesina, Di Tella and MacCulloch (2004) } \\
\text { Ohtake (2012) }\end{array}$ \\
\hline & $\begin{array}{l}\text { Unemployment is negatively related to } \\
\text { subjective well-being. }\end{array}$ & Dolan, Peasgood and White (2008) \\
\hline & \multirow[t]{2}{*}{$\begin{array}{l}\text { Voluntary part-time employees are } \\
\text { happier than full-time employees. }\end{array}$} & Nikolova and Graham (2014) \\
\hline \multirow{7}{*}{ Income } & & Tsou and Liu (2001) \\
\hline & \multirow{6}{*}{$\begin{array}{l}\text { Individuals' personal income affects } \\
\text { their happiness. }\end{array}$} & Pouwels, Siegers and Vlasblom (2008) \\
\hline & & Selim (2008) \\
\hline & & Biswas-Diener, Vitters $\varnothing$ and Diener (2010) \\
\hline & & Knabe and Rätzel (2010) \\
\hline & & Angner et al. (2011) \\
\hline & & Campbell (2013) \\
\hline \multirow{4}{*}{ Friendship } & \multirow{4}{*}{$\begin{array}{l}\text { Positive friendship at the workplace } \\
\text { influences employee happiness }\end{array}$} & Hamilton (2007) \\
\hline & & Demir et al. (2011) \\
\hline & & Bader, Hashim and Zaharim (2013) \\
\hline & & Snow (2013) \\
\hline \multirow{3}{*}{ Work activities } & \multirow{2}{*}{$\begin{array}{l}\text { Specific work activities are positively } \\
\text { associated with happiness. }\end{array}$} & Waryszak and King (2001) \\
\hline & & Tadic et al. (2013) \\
\hline & $\begin{array}{l}\text { perceive that their job duties are } \\
\text { significant. }\end{array}$ & Golparvar and Abedini (2014) \\
\hline
\end{tabular}


The above-mentioned constructs are the key factors which influence happiness at the workplace. This paper assumed that these factors can make employees happy, which in turn their performance would be improved (Atkinson \& Hall, 2011). However, people in each region (e.g. Asia and Europe) or in each culture have their own philosophy of happiness (Schwartz, 2007; Trung, Cheong, Nghi, \& Kim, 2013). This paper presents a conceptual framework which is composed of independent variables (employment status, income, friendship, and work activities), dependent variable (happiness at the workplace), and moderating variable (cultural values) (see Figure 1).

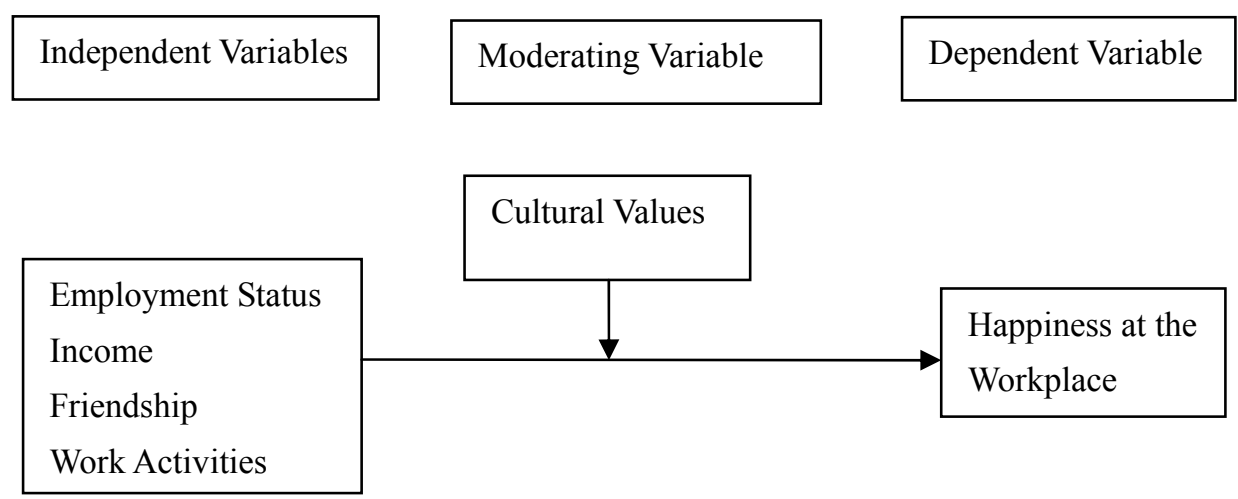

Figure 1. A conceptual framework of happiness at the workplace

Happiness at the workplace is hypothesized to be influenced by several factors such as employment status, income, friendship, and work activities. The relationship between these factors and happiness at the workplace is moderated by cultural values.

\subsection{Employment Status}

Employment status refers to an employment-related situation in which an individual is being held (Foroutan, 2011). Individuals' happiness depends on their employment status (Frey \& Stutzer, 2000b; Ha \& Kim, 2013) (e.g. employed or unemployed (Jiang et al., 2012), full-time or part-time employment (Berger, 2009)). Employees usually seek for employment security (Silla, De Cuyper, Gracia, Peiró, \& De Witte, 2009). Unemployment status makes people unhappy (Escott \& Buckner, 2013). Their experience of unemployment or fear of unemployment can reduce happiness (Ohtake, 2012). Particularly, individuals who value family relationships may be more unhappy with unemployment status if it causes their family difficulties (Campbell, 2013). A number of studies have confirmed that unemployment affects happiness, but part-time and full-time employment that may affect employee happiness are needed to be investigated further (Berger, 2009). A study of maternal employment and happiness by Berger (2009) states that part-time employees have lower life satisfaction than full-time employees. Nevertheless, voluntary part-time employees who choose not to work full-time are happier than those full-time employees (Nikolova \& Graham, 2014).

\subsection{Income}

Income includes the wage and salary income earned by an individual (Mathur, 2012). A study of income and happiness by Caporale, Georgellis, Tsitsianis and Yin (2009) confirms that there is a strong relationship between a person's income and life satisfaction. This is because people who have higher income have more opportunities to buy desired goods and services (Frey \& Stutzer, 2002; Schnittker, 2008). Even though people who gain higher income seem to be happier people, their happiness level is affected by working hours (Binswanger, 2006; Paul \& Guilbert, 2013). People may be unsatisfied with their jobs if they have long working hours (Georgellis, Lange, \& Tabvuma, 2012).

Furthermore, people compare their own income with others (Lembregts \& Pandelaere, 2014; Oshio \& Kobayashi, 2011). They are likely to be happy when they perceive income equality (De Prycker, 2010). Oshio and Kobayashi (2011) contend that individuals who experience income inequality are less happy. In contrast, Hopkins (2008) argues that income inequality can positively affect happiness of some competitive people who gain more income than others. This is because competitive people try to make the difference between their own and others' rewards (Brody, 2010). They may be happy with higher income even if it is unequal to those people (Hopkins, 2008). 


\subsection{Friendship}

Friendship is defined as a close relationship among friends (Huang, 2008). People express their friendship through emotion and behavior (Huang, 2008; Spencer, 2012). Friendship at the workplace refers to individuals' friendship with their peers, subordinates, and superiors (Austin, 2009; Lee, 2005; Mao \& Hsieh, 2012). Friendship at the workplace has a positive impact on organizational productivity and employees' work attitudes towards their jobs (Song, 2005). Many studies show the link between interpersonal relationship and happiness (Demir \& Davidson, 2013; Søraker, 2012; Westaway, Olorunju, \& Rai, 2007). Positive friendship not only influences happiness of employees but also affects productivity (Bader et al., 2013). Friendship groups are more committed to their work and lead to higher productivity (Dotan, 2007). Employees who have meaningful friendship are happier than those who are alone (Snow, 2013). Consistently, Wright (2005) asserts that lonely people are less happy. People who have significant friendships may be happy because good friends are willing to behave positively to each other (Simon, Judge, \& Halvorsen-Ganepola, 2010). It should be highlighted that happy employees are mostly sociable people who have more friends (Ganser, 2012).

\subsection{Work Activities}

Work activities are the activities or duties that are performed by workers (Siccama, 2006). Some workers are happy with their work activities while some workers have negative experiences at work (Siegall \& McDonald, 2004). Individual could have different levels of happiness during different work activities (Tadić et al., 2013). They may happy to perform specific work activities (Tadić et al., 2013; Waryszak \& King, 2001). Martin (2008) argues that people feel happy when they pursue meaningful activities. Thus, managers should know how to manage the meaning of work for employees (Cleavenger \& Munyon, 2013; Vasconcelos, 2008). If employees perceive significance and meaning of work, they may be happy to do their work (Dimitrov, 2012; MacMillan, 2009).

\subsection{Cultural Values}

Cultural values are "belief systems that a society is committed to and that are handed down from one generation to the next" (Hassan, 2011, p. 111). A study by Downie, Koestner and Chua (2007) presents that cultural values can support an individual's self-determination to the happiness in diverse countries. The study shows the mean level differences of happiness across countries (Downie et al., 2007). Similarly, this paper assumed that the above-mentioned factors (employment status, income, friendship, and work activities) do not have the same effect to employee happiness in different cultures. The conceptions of happiness may vary among different societies or cultures (Lu, Gilmour, \& Kao, 2001). People from different cultures (e.g. Western and Eastern cultures) value different things (Goos, 2012; Lee, Scandura \& Sharif, 2014). Western cultural values are mainly focused on individualism that views each individual as an autonomous person (Cho, Thyroff, Rapert, Part, \& Lee, 2013; Goh, Lee, \& Salleh, 2009). Individualistic people place a high value on self-interests and personal goals (Rego \& Cunha, 2009). Hence, their happiness is based on personal factors (e.g. personal attitudes and beliefs) (Ram, 2010).

Eastern cultural values are emphasized on collectivism (Shao \& Skarlicki, 2014). In collectivistic societies, group goals are more important than personal goals (Zhang, Van Doorn, \& Leeflang, 2014). They believe that an individual's personal goals should not threaten group harmony (Ayçiçegi-Dinn \& Caldwell-Harris, 2011). However, individuals can have both Eastern and Western cultures since they are exposed to one another's culture in their everyday lives (Leung, Hou, Gati, \& Li, 2011; Parker, Haytko, \& Hermans, 2009).

\section{Discussion}

Employees are happy when they experience stable employment (Scherer, 2009). Permanent employees seem to be more satisfied with their jobs than temporary employees (Ong \& Shah, 2012; Scherer, 2009). Sora, Caballer and Peiró (2010) maintain that temporary employees perceive a high level of job insecurity. Unstable employment not only makes employees feel unhappy but also affects the rate of employee turnover and organizational performance (Dike, 2011). This is because temporary employees are more likely to intend to leave their jobs than permanent employees (Sora et al., 2010).

Many studies (e.g. Gebremariam, Gebremedhin, \& Schaeffer, 2010; Rotaru, 2014) show the link between employment and income growth. Employment can be considered as an important source of income (Zuvekas \& Hill, 2000). People who have better employment status (i.e. stable employment) gain higher income (Shlay, Weinraub, Harmon, \& Tran, 2004). They may be happier than those who have lower employment status and gain lower income (Caporale et al., 2009). Furthermore, it should be noted that self-employed people seem to be more satisfied with work than those who are employed in organizations (Benz \& Frey, 2008). Employed and 
self-employed people have different work processes that might have an impact to their happiness level (Benz \& Frey, 2008). As a result, this paper views work activities as one of happiness constructs. People find the kinds of work tasks that are matched with their interests (Porfeli \& Mortimer, 2010). The individuals' interests can be concerned with meaning of work (Michaelson, 2011). Some people are probably happy to pursue the meaningful work (Grady \& McCarthy, 2008). An understanding of factors contributing to meaning of work is useful for the organizations to provide employees with meaningful work (Michaelson, Pratt, Grant, \& Dunn, 2014).

In addition to the three happiness constructs mentioned earlier, people value friendship at the workplace as important to their work life (Mao, Hsieh, \& Chen, 2012). Friendship at the workplace facilitates the exchange of resources and ideas among employees (Chang, 2013; D'Cruz \& Noronha, 2011). It enhances employees' attitudes towards work and work performance (Lin, 2010). Employees who are happy with work and have positive friendships at the workplace are less likely to leave their jobs (Dike, 2011). However, Mao and Hsieh (2012) argue that employees with different work levels may differ in friendship expectation. Higher-level employees had lower expectation for friendship at work (Mao \& Hsieh, 2012). Thus, employees performing different work levels could differ in happiness of friendship as well.

Maintaining employee happiness is necessary to ensure availability of workforce (Asiyabi \& Mirabi, 2012; Lindorff, 2010). According to the changing world of work, most employees change their jobs several times (Clarke, 2007; Sun \& Wang, 2011). Many organizations have difficulties retaining the high talent employees who have high potential to accomplish organizational goals (Chaudhry \& Shah, 2011; Kumar \& Dhamodaran, 2013). It can be said that enhancing happiness at the workplace is a challenge for maximizing organizational productivity (Chaudhry \& Shah, 2011).

\section{Conclusion}

In this paper, the relationship between independent variables and happiness at the workplace is hypothesized to be moderated by cultural values. Employee happiness may differ in different cultural contexts. The research on happiness issues should be explored further to include diverse cultures as well as various types of organizations (Sloan, 2005). Since the notion of happiness is crucial for organizational performance and productivity, HR managers need to design and manage a workplace to enhance employee happiness (Gavin \& Mason, 2004; Rego \& Cunha, 2008). Happy employees bring their happiness from the office to their home; likewise they also transfer their happiness from their home to the office (Asiyabi \& Mirabi, 2012). This suggests that there is a possible close interrelation between an individual's work and life.

\section{Acknowledgments}

We would like to express our special thanks to Prince of Songkla University (PSU), Pattani Campus and Universiti Utara Malaysia (UUM) for providing us with necessary resources. We also would like to thank the staff and lecturers for all their help and support.

\section{References}

Alesina, A., Di Tella, R., \& MacCulloch, R. (2004). Inequality and happiness: Are Europeans and Americans different? Journal of Public Economics, 88, 2009-2042. http://dx.doi.org/10.1016/j.jpubeco.2003.07.006

Angner, E., Hullett, S., \& Allison, J. J. (2011). "I'll die with the hammer in my hand": John Henryism as a predictor of happiness. Journal of Economic Psychology, 32, 357-366. http://dx.doi.org/10.1016/j.joep.2011. 01.002

Asiyabi, M., \& Mirabi, V. (2012). Investigation of contributing factors in employees desertion in power engineering consultants (Moshanir) company. Interdisciplinary Journal of Contemporary Research in Business, 4(6), 1183-1199.

Atkinson, C., \& Hall, L. (2011). Flexible working and happiness in the NHS. Employee Relations, 33(2), 88-105. http://dx.doi.org/10.1108/01425451111096659

Austin, C. (2009). An investigation of workplace friendships and how it influences career advancement and job satisfaction: A qualitative case study. Unpublished PhD's thesis. Capella University, United States.

Ayçiçegi-Dinn, A., \& Caldwell-Harris, C. L. (2011). Individualism-collectivism among Americans, Turks and Turkish immigrants to the U.S. International Journal of Intercultural Relations, 35, 9-16. http://dx.doi.org/ 10.1016/j.ijintrel.2010.11.006

Aydin, N. (2012). A grand theory of human nature and happiness. Humanomics, 28(1), 42-63. http://dx.doi.org $/ 10.1108 / 08288661211200988$

Bader, H. A. M., Hashim, I. H. M., \& Zaharim, N. M. (2013). Workplace friendships among bank employees in 
Eastern Libya. Digest of Middle East Studies, 22(1), 94-116. http://dx.doi.org/10.1111/dome.12020

Baran, B. E., Shanock, L. R., \& Miller, L. R. (2012). Advancing organizational support theory into the twenty-first century world of work. Journal of Business and Psychology, 27(2), 123-147. http://dx.doi. org/10.1007/s10869-011-9236-3

Barmby, T., Bryson, A., \& Eberth, B. (2012). Human capital, matching and job satisfaction. Economics Letters, 117, 548-551. http://dx.doi.org/10.1016/j.econlet.2012.07.026

Benrazavi, S. R., \& Silong, A. D. (2013). Employees' job satisfaction and its influence on willingness to work in teams. Journal of Management Policy and Practice, 14(1), 127-140.

Benz, M., \& Frey, B. S. (2008). Being independent is a great thing: Subjective evaluations of self-employment and hierarchy. Economica, 75, 362-383. http://dx.doi.org/10.1111/j.1468-0335.2007.00594.x

Berger, E. M. (2009). Maternal employment and happiness: The effect of non-participation and part-time employment on mothers' life satisfaction. Retrieved June 11, 2014, from http://smye2009.org/file/334_ Berger.pdf

Bhattacharjee, D., \& Bhattacharjee, M. (2010). Measuring happiness at work place. ASBM Journal of Management, 3(1/2), 112-125.

Binswanger, M. (2006). Why does income growth fail to make us happier? Searching for the treadmills behind the paradox of happiness. The Journal of Socio-Economics, 35, 366-381. http://dx.doi.org/10.1016 /j.socec.2005.11.040

Biswas-Diener, R., Vittersø, J., \& Diener, E. (2010). The Danish effect: Beginning to explain high well-being in Denmark. Social Indicators Research, 97, 229-246. http://dx.doi.org/10.1007/s11205-009-9499-5

Björke, A. (2012). Is there happiness therein? BM and HRCA for self-employed. Journal of Human Resource Costing \& Accounting, 16(2), 95-111. http://dx.doi.org/10.1108/14013381211284236

Brody, L. (2010). On behalf of another: Exploring social value orientation and responses to injustice. Unpublished PhD's thesis. Emory University, United States.

Campbell, B. (2013). Value orientation and unemployment: A multiple case study of eight unemployed participants. Unpublished PhD's thesis. Saybrook University, United States.

Caporale, G. M., Georgellis, Y., Tsitsianis, N., \& Yin, Y. P. (2009). Income and happiness across Europe: Do reference values matter? Journal of Economic Psychology, 30, 42-51. http://dx.doi.org/10.1016/j.joep.2008. 06.004

Carleton, E. L. (2009). Happiness at work: Using positive psychology interventions to increase worker well-being. Unpublished master's thesis. Saint Mary's University, Canada.

Chang, J. (2013). Affect, trust and friendship: A case study of Chinese and Zambian relationships at the workplace. International Journal of Business Anthropology, 4(1), 38-61.

Chaudhry, M. A., \& Shah, N. (2011). Impact of supportive leadership and organizational learning culture as a moderator on the relationship of psychological empowerment and organizational commitment. Journal of Business Strategies, 5(1), 39-50.

Cho, Y., Thyroff, A., Rapert, M. I., Part, S., \& Lee, H. J. (2013). To be or not to be green: Exploring individualism and collectivism as antecedents of environmental behavior. Journal of Business Research, 66, 1052-1059. http://dx.doi.org/10.1016/j.jbusres.2012.08.020

Chong, V. K., \& Eggleton, I. R. C. (2007). The impact of reliance on incentive-based compensation schemes, information asymmetry and organizational commitment on managerial performance. Management Accounting Research, 18, 312-342. http://dx.doi.org/10.1016/j.mar.2007.04.002

Clarke, M. (2007). Where to from here? Evaluating employability during career transition. Journal of Management and Organization, 13, 196-211. http://dx.doi.org/10.5172/jmo.2007.13.3.196

Cleavenger, D. J., \& Munyon, T. P. (2013). It's how you frame it: Transformational leadership and the meaning of work. Business Horizons, 56, 351-360. http://dx.doi.org/10.1016/j.bushor.2013.01.002

Colakoglu, S., Lepak, D. P., \& Hong, Y. (2006). Measuring HRM effectiveness: Considering multiple stakeholders in a global context. Human Resource Management Review, 16, 209-218. http://dx.doi.org/10. 1016/j.hrmr.2006.03.003

Connell, J., Gough, R., McDonnell, A., \& Burgess, J. (2014). Technology, work organisation and job quality in the service sector: An introduction. Labour and Industry, 24(1), 1-8. http://dx.doi.org/10.1080/ 10301763.2013.877117 
D’Cruz, P., \& Noronha, E. (2011). The limits to workplace friendship-Managerialist HRM and bystander behaviour in the context of workplace bullying. Employee Relations, 33(3), 269-288. http://dx.doi.org/10. 1108/01425451111121777

Dalal, R. S., Baysinger, M., Brummel, B. J., \& Lebreton, J. M. (2012). The relative importance of employee engagement, other job attitudes, and trait affect as predictors of job performance. Journal of Applied Social Psychology, 42(S1), E295-E325. http://dx.doi.org/10.1111/j.1559-1816.2012.01017.x

De Prycker, V. (2010). Happiness on the political agenda? PROS and CONS. Journal of Happiness Studies, 11, 585-603. http://dx.doi.org/10.1007/s10902-010-9205-y

Demir, M., \& Davidson, I. (2013). Toward a better understanding of the relationship between friendship and happiness: Perceived responses to capitalization attempts, feelings of mattering, and satisfaction of basic psychological needs in same-sex best friendships as predictors of happiness. Journal of Happiness Studies, 14(2), 525-550. http://dx.doi.org/10.1007/s10902-012-9341-7

Demir, M., Özen, A., Doğan, A., Bilyk, N. A., \& Tyrell, F. A. (2011). I matter to my friend, therefore I am happy: Friendship, mattering, and happiness. Journal of Happiness Studies, 12, 983-1005. http://dx.doi.org/10.1007 /s10902-010-9240-8

Dike, D. (2011). Quantitative correlational study of organizational culture perception, employment length, and employee turnover in fast-food restaurants. Unpublished doctoral dissertation. University of Phoenix, United States.

Dimitrov, D. (2012). Sources of meaningfulness in the workplace: A study in the US hospitality sector. European Journal of Training and Development, 36(2/3), 351-371. http://dx.doi.org/10.1108/03090591211204788

Dolan, P., Peasgood, T., \& White, M. (2008). Do we really know what makes us happy? A review of the economic literature on the factors associated with subjective well-being. Journal of Economic Psychology, 29, 94-122. http://dx.doi.org/10.1016/j.joep.2007.09.001

Dotan, H. (2007). Friendship ties at work: Origins, evolution and consequences for managerial effectiveness. Unpublished PhD's thesis. University of California, United States.

Downie, M., Koestner, R., \& Chua, S. N. (2007). Political support for self-determination, wealth, and national subjective well-being. Motivation and Emotion, 31, 174-181. http://dx.doi.org/10.1007/s11031-007-9070-0

Dulk, L. D., Groeneveld, S., Ollier-Malaterre, A., \& Valcour, M. (2013). National context in work-life research: A multi-level cross-national analysis of the adoption of workplace work-life arrangements in Europe. European Management Journal, 31, 478-494. http://dx.doi.org/10.1016/j.emj.2013.04.010

Escott, K., \& Buckner, L. (2013). Improving employment and women's well-being in regeneration programmes. International Journal of Public Sector Management, 26(3), 250-263. http://dx.doi.org/10.1108/IJPSM-102011-0125

Fereidouni, H. G., Najdi, Y., \& Amiri, R. E. (2013). Do governance factors matter for happiness in the MENA region? International Journal of Social Economics, 40(12), 1028-1040. http://dx.doi.org/10.1108/IJSE-112012-0208

Fisher, C. D. (2010). Happiness at work. International Journal of Management Reviews, 12, $384-412$. http://dx.doi.org/10.1111/j.1468-2370.2009.00270.x

Foroutan, Y. (2011). Multiculturalism and women's employment: A sociological perspective. New Zealand Sociology, 26(1), 122-142.

Frey, B. S., \& Stutzer, A. (2000a). Maximizing happiness. German Economic Review, 1(2), $145-167$. http://dx.doi.org/10.1111/1468-0475.00009

Frey, B. S., \& Stutzer, A. (2000b). Happiness, economy and institutions. The Economic Journal, 110(466), 918-938. http://dx.doi.org/10.1111/1468-0297.00570

Frey, B. S., \& Stutzer, A. (2002). The economics of happiness. World Economics, 3(1), 1-17.

Ganser, W. G. (2012). Pursuing happiness with gratitude and kindness: An experimental intervention comparing cognitive and behavioral activities. Unpublished master's thesis, Northern Arizona University, United States.

Gavin, J. H., \& Mason, R. O. (2004). The virtuous organization: The value of happiness in the workplace. Organizational Dynamics, 33(4), 379-392. http://dx.doi.org/10.1016/j.orgdyn.2004.09.005

Gebremariam, G. H., Gebremedhin, T. G., \& Schaeffer, P. V. (2010). Analysis of county employment and income growth in Appalachia: A spatial simultaneous-equations approach. Empirical Economics, 38, 23-45. http://dx.doi.org/10.1007/s00181-009-0254-1 
Georgellis, Y., Lange, T., \& Tabvuma, V. (2012). The impact of life events on job satisfaction. Journal of Vocational Behavior, 80, 464-473. http://dx.doi.org/10.1016/j.jvb.2011.12.005

Goh, J. W. P., Lee, O. K., \& Salleh, H. (2009). A cross-cultural investigation of teachers' and reporting officers' self-ratings on teaching and leadership skills across Singapore and Bahrain. International Journal of Educational Research, 48, 258-273. http://dx.doi.org/10.1016/j.ijer.2009.12.001

Golparvar, M., \& Abedini, H. (2014). The relationship between spirituality and meaning at work and the job happiness and psychological well-being. International Journal of Management and Sustainability, 3(3), $160-175$.

Goos, J. M. (2012). Risk for workaholism: A cross-cultural study of cultural value orientation, social support, and life satisfaction. Unpublished doctoral dissertation. Roosevelt University, United States.

Grady, G., \& McCrathy, A. M. (2008). Work-life integration: Experiences of mid-career professional working mothers. Journal of Managerial Psychology, 23(5), 599-622. http://dx.doi.org/10.1108/0268394081 0884559

Ha, S. E., \& Kim, S. (2013). Personality and subjective well-being: Evidence from South Korea. Social Indicators Research, 111, 341-359. http://dx.doi.org/10.1007/s11205-012-0009-9

Hales, J., \& Williamson, M. G. (2010). Implicit employment contracts: The limits of management reputation for promoting firm productivity. Journal of Accounting Research, 48(1), 51-80. http://dx.doi.org/10.1111/j. 1475-679X.2009.00352.x

Hamilton, E. A. (2007). Firm friends: Examining functions and outcomes of workplace friendship among law firm associates. Unpublished PhD's thesis. Boston College, United States.

Hassan, S. H. (2011). Consumption of functional food model for Malay Muslims in Malaysia. Journal of Islamic Marketing, 2(2), 104-124. http://dx.doi.org/10.1108/17590831111139839

Hopkins, E. (2008). Inequality, happiness and relative concerns: What actually is their relationship? Journal of Economic Inequality, 6, 351-372. http://dx.doi.org/10.1007/s10888-008-9081-4

Hosie, P., Willemyns, M., \& Sevastos, P. (2012). The impact of happiness on managers' contextual and task performance. Asia Pacific Journal of Human Resources, 50, 268-287. http://dx.doi.org/10.1111/j.1744-7941. 2012.00029.x

Huang, Y. (2008). Conceptualizations of friendship between Chinese international students and U.S. nationals. Unpublished master's thesis. Texas Tech University, United States.

Jiang, S., Lu, M., \& Sato, H. (2012). Identity, inequality, and happiness: Evidence from urban China. World Development, 40(6), 1190-1200. http://dx.doi.org/10.1016/j.worlddev.2011.11.002

Johnston, C. S., Luciano, E. C., Maggiori, C., Ruch, W., \& Rossier, J. (2013). Validation of the German version of the Career Adapt-Abilities Scale and its relation to orientations to happiness and work stress. Journal of Vocational Behavior, 83, 295-304. http://dx.doi.org/10.1016/j.jvb.2013.06.002

Klehe, U., Zikic, J., Van Vianen, A. E. M., \& De Pater, I. E. (2011). Career adaptability, turnover and loyalty during organizational downsizing. Journal of Vocational Behavior, 79, 217-229. http://dx.doi.org/10.1016/j. jvb.2011.01.004

Knabe, A., \& Rätzel, S. (2010). Income, happiness, and the disutility of labour. Economics Letters, 107, 77-79. http://dx.doi.org/10.1016/j.econlet.2009.12.032

Koukoulaki, T. (2010). New trends in work environment-New effects on safety. Safety Science, 48, 936-942. http://dx.doi.org/10.1016/j.ssci.2009.04.003

Kumar, S. P. P., \& Dhamodaran, M. (2013). An empirical study on talent retention strategy by BPO's in India. Interdisciplinary Journal of Cntemporary Research in Business, 5(4), 207-219.

Lee, H. E. (2005). Exploration of the relationship between friendship at work and job satisfaction: An application of balance theory. Unpublished master's thesis. Michigan State University, United States.

Lee, K., Scandura, T. A., \& Sharif, M. M. (2014). Cultures have consequences: A configural approach to leadership across two cultures. The Leadership Quarterly, 25, 692-710. http://dx.doi.org/10.1016/j.leaqua. 2014.03.003

Lembregts, C., \& Pandelaere, M. (2014). A 20\% income increase for everyone? The effect of relative increases in income on perceived income inequality. Journal of Economic Psychology, 43, 37-47. http://dx.doi.org/10. 1016/j.joep.2014.04.008

Leung, S. A., Hou, Z., Gati, I., \& Li, X. (2011). Effects of parental expectations and cultural-values orientation 
on career decision-making difficulties of Chinese University students. Journal of Vocational Behavior, 78, 11-20. http://dx.doi.org/10.1016/j.jvb.2010.08.004

Lin, C. (2010). Relationship between job position, job attributes, and workplace friendship: Taiwan and China. Journal of Technology Management in China, 5(1), 55-68. http://dx.doi.org/10.1108/17468771011032796

Lindorff, M. (2010). The personal values of tomorrow's workforce: Similarities and differences across sex and nationality. Journal of Management and Organization, 16, 353-368. http://dx.doi.org/10.5172/jmo.16.3.353

Lu, L., Gilmour, R., \& Kao, S. (2001). Cultural values and happiness: An East-West dialogue. The Journal of Social Psychology, 141(4), 477-493. http://dx.doi.org/10.1080/00224540109600566

MacMillan, S. (2009). Towards an existential approach to the meaning of work. Unpublished PhD's thesis. Saint Mary's University, Canada.

Mao, H. \& Hsieh, A. (2012). Organizational level and friendship expectation at work. Asian Business \& Management, 11(41), 485-506. http://dx.doi.org/10.1057/abm.2012.14

Mao, H., Hsieh, A., \& Chen, C. (2012). The relationship between workplace friendship and perceived job significance. Journal of Management and Organization, 18(2), 247-262. http://dx.doi.org/10.5172/jmo. 2012.18.2.247

Martin, M. W. (2008). Paradoxes of happiness. Journal of Happiness Studies, 9(2), 171-184. http://dx.doi.org/10. 1007/s 10902-007-9056-3

Mathur, A. (2012). Health expenditures and personal bankruptcies. Health, 4(12), 1305-1316. http://dx.doi.org /10.4236/health.2012.412192

Michaelson, C. (2011). Whose responsibility is meaningful work? Journal of Management Development, 30(6), 548-557. http://dx.doi.org/10.1108/02621711111135152

Michaelson, C., Pratt, M. G., Grant, A. M., \& Dunn, C. P. (2014). Meaningful work: Connecting business ethics and organization studies. Journal of Business Ethics, 121, 77-90. http://dx.doi.org/10.1007/s10551-013$1675-5$

Mohanty, M. S. (2009). Effects of positive attitude on happiness and wage: Evidence from the US data. Journal of Economic Psychology, 30, 884-897. http://dx.doi.org/10.1016/j.joep.2009.08.010

Naff, A. (2012). Investing in happiness: An analysis of the contributing factors to the positive professional work environment. Unpublished master's thesis. Liberty University, United States.

Nikolova, M., \& Graham, C. (2014). Employment, late-life work, retirement, and well-being in Europe and the United States. IZA Journal of European Labor Studies, 3(5), 1-30.

Ohtake, F. (2012). Unemployment and happiness. Japan Labor Review, 9(2), 59-74.

Ong, R., \& Shah, S. (2012). Job security satisfaction in Australia: Do migrant characteristics and gender matter? Australia Journal of Labour Economics, 15(2), 123-139.

Oshio, T., \& Kobayashi, M. (2011). Area-level income inequality and individual happiness: Evidence from Japan. Journal of Happiness Studies, 12(4), 633-649. http://dx.doi.org/10.1007/s10902-010-9220-z

Parker, R. S., Haytko, D. L., \& Hermans, C. M. (2009). Individualism and collectivism: Reconsidering old assumptions. Journal of International Business Research, 8(1), 127-139.

Paul, S., \& Guilbert, D. (2013). Income-happiness paradox in Australia: Testing the theories of adaption and social comparison. Economic Modelling, 30, 900-910. http://dx.doi.org/10.1016/j.econmod.2012.08.034

Porfeli, E. J., \& Mortimer, J. T. (2010). Intrinsic work value-reward dissonance and work satisfaction during young adulthood. Journal of Vocational Behavior, 76, 507-519. http://dx.doi.org/10.1016/j.jvb.2010.01.004

Pouwels, B., Siegers, J., \& Vlasblom, J. D. (2008). Income, working hours, and happiness. Economics Letters, 99, 72-74. http://dx.doi.org/10.1016/j.econlet.2007.05.032

Quick, J. C., \& Quick, J. D. (2004). Health, happy, productive work: A leadership challenge. Organizational Dynamics, 33(4), 329-337. http://dx.doi.org/10.1016/j.orgdyn.2004.09.001

Quinlan, M. (2012). The 'pre-invention' of precarious employment: The changing world of work context. The Economic and Labour Relations Review, 23(4), 3-24. http://dx.doi.org/10.1177/103530461202300402

Ram, S. I. (2010). Exposure to Western culture in relation to individualism, collectivism and subjective well-being, in India. Unpublished PhD's thesis. Illinois Institute of Technology, United States.

Rego, A., \& Cunha, M. P. (2008). Authentizotic climates and employee happiness: Pathways to individual performance? Journal of Business Research, 61, 739-752. http://dx.doi.org/10.1016/j.jbusres.2007.08.003 
Rego, A., \& Cunha, M. P. (2009). How individualism-collectivism orientations predict happiness in a collectivistic context. Journal of Happiness Studies, 10, 19-35. http://dx.doi.org/10.1007/s10902-0079059-0

Rotaru, P. C. (2014). Empirical study on regional employment rate in Romania. Procedia-Social and Behavioral Sciences, 109, 1365-1369. http://dx.doi.org/10.1016/j.sbspro.2013.12.638

Saari, L. M., \& Judge, T. A. (2004). Employee attitudes and job satisfaction. Human Resource Management, 43(4), 395-407. http://dx.doi.org/10.1002/hrm.20032

Salis, S., \& Williams, A. M. (2010). Knowledge sharing through face-to-face communication and labour productivity: Evidence from British workplaces. British Journal of Industrial Relations, 48(2), 436-459. http://dx.doi.org/10.1111/j.1467-8543.2009.00762.x

Samnani, A., \& Singh, P. (2014). Performance-enhancing compensation practices and employee productivity: The role of workplace bullying. Human Resource Management Review, 24, 5-16. http://dx.doi.org/10.1016/j. hrmr.2013.08.013

Scherer, S. (2009). The social consequences of insecure jobs. Social Indicators Research, 93, 527-547. http://dx.doi.org/10.1007/s11205-008-9431-4

Schnittker, J. (2008). Happiness and success: Genes, families, and the psychological effects of socioeconomic position and social support. American Journal of Sociology, 114, S233-S259. http://dx.doi.org/10.1086/59 2424

Schwartz, S. J. (2007). The applicability of familism to diverse ethnic groups: A preliminary study. The Journal of Social Psychology, 147(2), 101-118. http://dx.doi.org/10.3200/SOCP.147.2.101-118

Selim, S. (2008). Life satisfaction and happiness in Turkey. Social Indicators Research, 88, 531-562. http://dx. doi.org/10.1007/s11205-007-9218-z

Shao, R., \& Skarlicki, D. P. (2014). Service employees' reactions to mistreatment by customers: A comparison between North America and East Asia. Perssonel Psychology, 67, 23-59. http://dx.doi.org/10.1111/peps. 12021

Shlay, A. B., Weinraub, M., Harmon, M., \& Tran, H. (2004). Barriers to subsidies: Why low-income families do not use child care subsidies. Social Science Research, 33, 134-157. http://dx.doi.org/10.1016/S0049-089X (03)00042-5

Siccama, C. J. (2006). Work activities of professionals who occupy the role of faculty support staff in online education programs. Unpublished doctoral dissertation. University of Massachusetts Lowell, United States.

Siegall, M., \& McDonald, T. (2004). Person-organization value congruence, burnout and diversion of resources. Personnel Review, 33(3), 291-301. http://dx.doi.org/10.1108/00483480410528832

Silla, I., De Cuyper, N., Gracia, F. J., Peiró, J. M., \& De Witte, H. (2009). Job insecurity and well-being: Moderation by employability. Journal of Happiness Studies, 10(6), 739-751. http://dx.doi.org/10.1007/s 10902-008-9119-0

Silla, I., Gracia, F. J., Maňas, M. A., \& Peiró, J. M. (2010). Job insecurity and employees' attitudes: The moderating role of fairness. International Journal of Manpower, 31(4), 449-465. http://dx.doi.org/10.1108/0 1437721011057029

Simmons, B. L. (2014). Organizational characteristics of happy organizations. In P. Y. Chen, \& C. L. Cooper (Eds.), Work and wellbeing (pp. 1-18). Hoboken: John Wiley \& Sons, Inc.

Simon, L. S., Judge, T. A., \& Halvorsen-Ganepola, M. D. K. (2010). In good company? A multi-study, multi-level investigation of the effects of coworker relationships on employee well-being. Journal of Vocational Behavior, 76, 534-546. http://dx.doi.org/10.1016/j.jvb.2010.01.006

Sloan, M. M. (2005). There is no happiness at work! Emotion management, inauthenticity, and psychological distress in the workplace. Unpublished PhD's thesis. Vanderbilt University, United States.

Snow, E. L. (2013). The impact of attachment on friendship satisfaction and correlates of well-being of older adult females. Unpublished master's thesis. California State University Long Beach, United States.

Song, S. H. (2005). Workplace friendship and its impact on employees' positive work attitudes-A comparative study of Seoul City and New Jersey state government public officials. Unpublished PhD's thesis. The State University of New Jersey, United States.

Sora, B., Caballer, A., \& Peiró, J. M. (2010). The consequences of job insecurity for employees: The moderator role of job dependence. International Labour Review, 149, 59-72. http://dx.doi.org/10.1111/j.1564-913X. 2010.00075.x 
Søraker, J. H. (2012). How shall I compare thee? Comparing the prudential value of actual and virtual friendship. Ethics and Information Technology, 14(3), 209-219. http://dx.doi.org/10.1007/s10676-012-9294-x

Spencer, S. V. C. (2012). The functions of verbal and nonverbal emotional disclosures to friends during early adolescence: A focus on closeness, friendship satisfaction, and internalizing symptoms. Unpublished PhD's thesis. The University at Buffalo, the State University of New York, United States.

Stiglbauer, B., \& Batinic, B. (2012). The role of Jahoda's latent and financial benefits for work involvement: A longitudinal study. Journal of Vocational Behavior, 81, 259-268. http://dx.doi.org/10.1016/j.jvb.2012.07.008

Sun, J. Y., \& Wang, G. G. (2011). Integrating disparate literatures on voluntary career transition and voluntary turnover-Implications for research in the Chinese context. Journal of Chinese Human Resource Management, 2(1), 23-42. http://dx.doi.org/10.1108/20408001111148711

Tabassi, A. A., \& Abu Bakar, A. H. (2009). Training, motivation, and performance: The case of human resource management in construction projects in Mashhad, Iran. International Journal of Project Management, 27, 471-480. http://dx.doi.org/10.1016/j.ijproman.2008.08.002

Tadić, M., Bakker, A. B., \& Oerlemans, W. G. M. (2013). Work happiness among teachers: A day reconstruction study on the role of self-concordance. Journal of School Psychology, 51, 735-750. http://dx.doi.org/10.1016 /j.jsp.2013.07.002

Thompson, G. M., \& Goodale, J. C. (2006). Variable employee productivity in workplace scheduling. European Journal of Operational Research, 170, 376-390. http://dx.doi.org/10.1016/j.ejor.2004.03.048

Trung, N. N., Cheong, K., Nghi, P. T., \& Kim, W. J. (2013). Relationship between socio-economic values and wellbeing: An overview research in Asia. Social Indicators Research, 111(2), 453-472. http://dx.doi.org/10. 1007/s11205-012-0014-z

Tsou, M., \& Liu, J. (2001). Happiness and domain satisfaction in Taiwan. Journal of Happiness Studies, 2, 269-288. http://dx.doi.org/10.1023/A:1011816429264

Van Praag, B. M. S., Romanov, D., \& Ferrer-i-Carbonell, A. (2010). Happiness and financial satisfaction in Israel: Effects of religiosity, ethnicity, and war. Journal of Economic Psychology, 31, 1008-1020. http://dx.doi.org /10.1016/j.joep.2010.08.008

Vasconcelos, A. F. (2008). Broadening even more the internal marketing concept. European Journal of Marketing, 42(11/12), 1246-1264. http://dx.doi.org/10.1108/03090560810903664

Waryszak, R., \& King, B. (2001). Managerial attitudes towards work activities in the hospitality and service industries. International Journal of Contemporary Hospitality Management, 13(4), 197-203. http://dx.doi. org/10.1108/09596110110389566

Westaway, M. S., Olorunju, S. A. S., \& Rai, L. J. (2007). Which personal quality of life domains affect the happiness of older South Africans? Quality of Life Research, 16(8), 1425-1438. http://dx.doi.org/10.1007 /s11136-007-9245-x

Wright, S. L. (2005). Loneliness in the workplace. Unpublished PhD's thesis. University of Canterbury, New Zealand.

Zhang, S., Van Doorn, J., \& Leeflang, P. S. H. (2014). Does the importance of value, brand and relationship equity for customer loyalty differ between Eastern and Western cultures? International Business Review, 23, 284-292. http://dx.doi.org/10.1016/j.ibusrev.2013.05.002

Zuvekas, S. H., \& Hill, S. C. (2000). Income and employment among homeless people: The role of mental health, health and substance abuse. The Journal of Mental Health Policy and Economics, 3, 153-163. http://dx.doi. org/10.1002/mhp.94

\section{Copyrights}

Copyright for this article is retained by the author(s), with first publication rights granted to the journal.

This is an open-access article distributed under the terms and conditions of the Creative Commons Attribution license (http://creativecommons.org/licenses/by/3.0/). 